\title{
PENGARUH MODEL PEMBELAJARAN BERBASIS MASALAH MENGGUNAKAN MACROMEDIA FLASH TERHADAP KEMAMPUAN PEMECAHAN MASALAH SISWA PADA MATERI POKOK FLUIDA DINAMIS KELAS XI SEMESTER II SMA NEGERI 2 KABANJAHE T.P.2015/2016
}

\author{
Seftia Agafe Br Barus dan Rappel Situmorang \\ Jurusan Fisika FMIPA Universitas Negeri Medan \\ situmorangrappel@gmail.com
}

Diterima: Desember 2016. Disetujui: Januari 2017. Dipublikasikan: Februari 2017

\begin{abstract}
ABSTRAK
Penelitian ini bertujuan untuk mengetahui pengaruh model pembelajaran berbasis masalah menggunakan macromediaflash terhadap kemampuan pemecahan masalah siswa pada materi pokok fluida dinamis kelas XI semester II SMA Negeri 2 Kabanjahe T.P. 2015/2016. Jenis penelitian ini adalah quasi experiment dengan desain penelitian yang digunakan adalah two group pretestposttest design.Populasi penelitian adalah seluruh siswa kelas XI-PMIPA Semester II yang terdiri dari 5 kelas paralel. Pengambilan sampel dilakukan dengan cara cluster random sampling. Kelas XIPMIPA1 yang berjumlah 30 0rang sebagai kelas eksperimen dengan menggunakan model pembelajaran berbasis masalah dan kelas XI-PMIPA 2 yang berjumlah 30 orang sebagai kelas kontrol dengan menggunakan pembelajaran konvensional. Hasil analisis data dengan uji-t satu pihak diperoleh nilai thitung $>$ tabel sehingga dari hasil analisis data menunjukkan bahwa terdapat pengaruh yang signifikan dari model pembelajaran berbasis masalah terhadap kemampuan pemecahan masalah siswa pada materi pokok fluida dinamis di kelas XI semester II SMA Negeri 2 Kabanjahe T.P. 2015/2016.
\end{abstract}

Kata kunci: pembelajaran berbasis masalah, kemampuan pemecahan masalah, aktivitas.

ABSTRACT

This study aimed to determine the effect of problem-based learning model using macromediaflash the problem solving ability of students in the subject matter of dynamic fluid second semester class XI SMA Negeri 2 Kabanjahe T.P. 2015/2016. This research is a quasi experimental research design used is a two-group pretest-posttest design.Populasi research are all students of class XI-PMIPA Semester II consisting of five parallel classes. Sampling was done by cluster random sampling. Class $X I-P M I P A 1$ totaling 30 Orang as an experimental class using problem-based learning model and class XI-PMIPA 2 totaling 30 people as classroom control using conventional learning. The results of data analysis using $t$-test of the party obtained tcount $>t$ table so that the results of data analysis showed that there is significant influence of problem based learning to problem-solving ability of students in the subject matter of fluid dynamic in class XI second half of SMA Negeri 2 Kabanjahe T.P. 2015/2016.

Keywords: problem-based learning, problem-solving ability, activity 
Seftia Agafe Br Barus dan Rappel Situmorang. Pengaruh Model Pembelajaran Berbasis Masalah Menggunakan Macromedia Flash TerhadapKemampuan Pemecahan Masalah Siswa Pada Materi Pokok Fluida Dinamis Kelas XI Semester II SMA Negeri 2 Kabanjahe T.P.2015/2016

\section{PENDAHULUAN}

Pendidikan merupakan suatu hal yang sangat penting untuk memajukan suatu negara dalam menghadapi kemajuan ilmu pengetahuan dan teknologi. Pendidikan berperan aktif dalam meningkatkan sumber daya manusia untuk mengikuti perkembang ilmu pengetahuan dan teknologi, maka pemerintah berupaya untuk terus meningkatkan kualitas pendidikan.

IPA merupakan ilmu yang mempelajari tentang gejala-gejala alam. Fisika sebagai salah satu unsur dalam IPA mempunyai peranan yang sangat penting dalam pengembangan teknologi masa depan, oleh karena itu dalam memacu ilmu pengetahuan dan teknologi proses pembelajaran fisika perlu mendapatkan perhatian yang lebih.

Bidang studi sains fisika sebagai bagian dari Ilmu Pengetahuan Alam (IPA) merupakan objek mata pelajaran yang menarik dan lebih banyak memerlukan pemahaman dari pada penghafalan. Namun, kenyataannya fisika sering dipandang siswa sebagai ilmu yang abstrak dengan teori dan soal-soal yang sulit.

Masalah utama dalam pembelajaran pada pendidikan formal (sekolah) dewasa ini adalah masih rendahnya daya serap peserta didik. Hal ini tampak dari rerata hasil belajar peserta didik yang senantiasa masih sangat memperihatinkan. Prestasi ini tentunya merupakan hasil kondisi pembelajaran yang masih bersifat konvensional dan tidak menyentuh ranah dimensi peserta didik itu sendiri, yaitu bagaimana sebenarnya belajar itu. Proses pembelajaran hingga dewasa ini masih memberikan dominasi guru dan tidak memberikan akses bagi anak didik untuk berkembang secara mandiri melalui penemuan dalam proses berpikirnya (Trianto, 2009: 5).

Model pembelajaran berdasarkan masalah adalah salah satu upaya solusinya, model pembelajaran ini dirancang dengan tujuan untuk membantu siswa mengembangkan kemampuan berfikir, mengembangkan kemampuan berfikir dan mengembangkan kemampuan dalam memecahkan masalah kehidupan sehari-hari (berbasis konstektual), sehingga siswa lebih paham terhadap konsep fisika yang berkaitan dengan kehidupan seharihari. Model pembelajaran berbasis masalah adalah model pembelajaran dengan pendekatan pembelajaran siswa pada masalah autentik sehingga siswa dapat menyusun pengetahuannya sendiri, menumbuhkembangkan keterampilan yang lebih tinggi dan inquiry, menghadirkan siswa dan meningkatkan kepercayaan diri sendiri (Arends, 2008: 41).

Menurut Rusman (2012: 230), masalah dapat mendorong keseriusan, inquiry dan berfikir dengan cara yang bermakna dan sangat kuat. Pembelajaran berbasis masalah adalah sebuah cara memanfaatkan masalah untuk menimbulkan motivasi belajar.

Menurut Rahayu (2015), berdasarkan penelitiannya diperoleh hasil belajar fisika siswa yang diberi pembelajaran dengan model pembelajaran berdasarkan masalah diperoleh rata-rata post-test sebesar 62,87. Hasil belajar fisika siswa yang diberi pembelajaran dengan model konvensional diperoleh rata-rata posttest sebesar 53,89. Hasil observasi aktivitas belajar siswa di kelas eksperimen dengan model pembelajaran berdasarkan masalah mengalami peningkatan yang positif. Kelemahan dari penelitian yang dilakukan ini kurang efisiennya waktu yang digunakan dalam proses pembelajaran dan kurang maksimalnya dalam membimbing siswa dan mengorganisasikan siswa untuk belajar.

Menurut Khodizah (2015), berdasarkan penelitiannya diperoleh hasil belajar fisika siswa yang diberi pembelajaran dengan model konvensional diperoleh rata-rata post-test sebesar 55,31 dan hasil belajar fisika siswa di kelas eksperimen dengan model pembelajaran berbasis masalah diperoleh rata-rata post-test siswa sebesar 73,28. Hasil observasi aktivitas belajar siswa di kelas eksperimen dengan model pembelajaran berbasis masalah memiliki efek yang lebih baik dibandingkan dengan pembelajaran konvensional dan hasil belajar afektif siswa lebih tinggi di kelas eksperimen 
daripada di kelas kontrol. Kelemahan dari penelitian ini adalah peneliti tidak bisa mengoptimalkan waktu saat praktikum berjalan, kemudian masih ada siswa yang kurang tertarik dengan pembelajarn berbasis masalah karena telah terbiasa mengikuti pembelajaran konvensional atau yang sudah diterapkan di kelas tersebut, seperti mencatat soal dan mengerjakan soal-soal fisika.

Menurut Sinaga (2015), berdasarkan penelitiannya diperoleh hasil belajar fisika siswa yang diberi pembelajaran dengan model konvensional diperoleh rata-rata post-test sebesar 56,97 dan hasil belajar fisika siswa di kelas eksperimen dengan model pembelajaran berbasis masalah diperoleh rata-rata post-test siswa sebesar 63,15. Hasil observasi aktivitas belajar siswa di kelas eksperimen dengan model pembelajaran berbasis masalah memiliki efek yang lebih baik dibandingkan dengan pembelajaran konvensional dan hasil belajar afektif siswa lebih tinggi di kelas eksperimen daripada di kelas kontrol. Kelemahan dari penelitian ini adalah kurangnya penguasaan kelas untuk menerapkan model PBL sehingga suasana kelas kurang kondusif.

Upaya yang akan dilakukan peneliti dalam penelitian ini untuk memperbaiki kelemahankelemahan peneliti sebelumnya : 1) membuat lembar kerja siswa (LKS) sesuai dengan indikator pencapaian pembelajaran kognitif, 3) Memanfaatkan waktu sebaik mungkin sesuai yang direncanakan sehingga proses pembelajaran berjalan dengan baik, 4) Mengorganisasikan kelompok sebaik mungkin agar anggotanya lebih sedikit dalam satu kelompok dan dan siswa dapat dikontrol dengan baik dalam proses pembelajaran, 5) Menguasai kelas agar suasana kelas kondusif pada saat proses belajar mengajar.

Berdasarkan latar belakang masalah di atas, adapun tujuan dari penelitian ini adalah untuk mengetahui pengaruh yang signifikan dalam penggunaan model pembelajaran berbasis masalah menggunakan macromedia flash terhadap kemampuan pemecahan masalah siswa.

\section{METODE PENELITIAN}

Penelitian ini telah dilaksanakandi SMA N 2 Kabanjahe yang beralamat di Jl. Letjen. Jamin Ginting, Kabupaten Karo. Waktu penelitian dimulai pada bulan April 2016 sampai bulan Mei 2016 semester genap pada T.P 2015/2016.

Sampel penelitian terdiri dari dua kelas yang diambil secara acak (cluster random sampling). Satu kelas sebagai kelas eksperimen yang berjumlah 30 orang diberi perlakuan menggunakan model pembelajaran berbasis masalah menggunakan macromedia flash, dan satu kelas sebagai kelas kontrol yang berjumlah 30 orang diberi perlakuan menggunakan pembelajaran konvensional.

Desain penelitian ini adalah Two Group Pretest - Posttest Design seperti ditunjukkan pada tabel 1

Tabel 1. Two Group Pretest - Posttest Design

\begin{tabular}{|l|l|l|l|}
\hline Kelompok/Kelas & Pretes & Perlakuan & Postes \\
\hline Eksperimen & $T_{1}$ & $X$ & $T_{2}$ \\
\hline Kontrol & $T_{1}$ & $Y$ & $T_{2}$ \\
\hline
\end{tabular}

Keterangan :

$T_{1}=$ Pretest diberikan kepada kelas eksperimen dan kelas kontrol sebelum perlakuan

$T_{2}=$ Posttest diberikan setelah perlakuan pada kelas eksperimen dan kelas kontrol

$X=$ Pengajaran dengan menerapkan model pembelajaran berbasis masalah menggunakan macromedia flash

$Y=$ Pengajaran dengan menerapkan model pembelajaran konvensional

$T_{1}=T_{2}$ (soal prettes sama dengan soal postest)

Pengujian untuk postes dilakukan uji $\mathrm{t}$ satu pihak, dengan rumus (sudjana, 2005: 239) :

Pengujian hipotesis penelitian digunakan uji t seperti dibawah ini :

$$
\mathrm{t}=\frac{\bar{X}_{1}-\bar{X}_{2}}{S \sqrt{\frac{1}{n_{1}}+\frac{1}{n_{2}}}}
$$

Kriteria pengujian adalah: terima $\mathrm{H}_{0}$ jika $-t_{1-1 / 2^{\alpha}}<t<t_{1-1 / 2^{\alpha}}$ dimana $t_{1-1 / 2^{\alpha}}$ didapat dari daftar distribusi $\mathrm{t}$ dengan $\mathrm{d}_{\mathrm{k}}=\left(\mathrm{n}_{1}+\mathrm{n}_{2}-2\right)$ dan $\alpha=0,05$ untuk harga $t$ lainnya $\mathrm{H}_{0}$ ditolak. 
Seftia Agafe Br Barus dan Rappel Situmorang. Pengaruh Model Pembelajaran Berbasis Masalah Menggunakan Macromedia Flash TerhadapKemampuan Pemecahan Masalah Siswa Pada Materi Pokok Fluida

Dinamis Kelas XI Semester II SMA Negeri 2 Kabanjahe T.P.2015/2016

\section{HASIL PENELITIAN DAN PEMBAHASAN}

Penelitian ini merupakan penelitian yang melibatkan dua kelompok sampel yaitu kelas eksperimen dan kelas kontrol. Kelas eksperimen diberikan perlakuan dengan menggunakan model pembelajaran berbasis masalah dan pada kelas kontrol diberlakukan pembelajaran konvensional. Diperoleh nilai rata-rata pretes kelas eksperimen adalah 31,67 dengan standar deviasi adalah 8,94 dan nilai rata-rata pretes pada kelas kontrol adalah 29,33 dengan standar deviasi adalah 9,97. Setelah diberikan perlakuan yang berbeda dimana kelas eksperimen diberikan model pembelajaran berbasis masalah menggunakan macromediaflash sedangkan kelas kontrol diberikan pembelajaran konvensional diperoleh rata-rata postes kelas eksperimen adalah 72,17 dengan standar deviasi adalah 9,07 dan nilai rata-rata postes kelas kontrol adalah 62,17 dengan standar deviasi adalah 11,27.

Pengujian hipotesis data hasil penelitian dilakukan dengan menggunakan uji t satu pihak untuk mengetahui pengaruh perlakuan yaitu penggunaan model pembelajaran berbasis masalah menggunakan macromedia flash terhadap kemampuan pemecahan masalah siswa di kelas eksperimen. Ringkasan perhitungan uji t postes pada kelas eksperimen dan kelas kontrol dapat dilihat pada tabel 2 .

Tabel 2. Ringkasan Perhitungan uji t postes

\begin{tabular}{|c|c|c|c|l|}
\hline Data & $\begin{array}{c}\text { Rata- } \\
\text { rata }\end{array}$ & thitung & tabel & \multicolumn{1}{|c|}{ Kesimpulan } \\
\hline $\begin{array}{c}\text { Postes } \\
\text { kelas } \\
\text { eskperim } \\
\text { en }\end{array}$ & 72,17 & & & $\begin{array}{l}\text { Kemampuan } \\
\text { pemecahan } \\
\text { masalah siswa di } \\
\text { kelas eksperimen } \\
\text { lebih tinggi } \\
\text { daripada di kelas } \\
\text { kontrol. }\end{array}$ \\
\hline $\begin{array}{c}\text { Postes } \\
\text { kelas } \\
\text { kontrol }\end{array}$ & 62,17 & & 1,73 \\
\hline
\end{tabular}

Pada tabel 2 diperoleh bahwa nilai postes thitung $>$ tabel yaitu 3,73>1,988 maka $\mathrm{H}_{0}$ ditolak dan terima $\mathrm{H}_{\mathrm{a}}$,dengan kata lain bahwa ada pengaruh yang signifikan dari model pembelajaran berbasis masalah menggunakan macromedia flash terhadap kemampuan pemecahan masalah siswa pada materi pokok Fluida Dinamis di kelas XI semester II SMA Negeri 2 Kabanjahe.

Penelitian kemampuan pemecahan masalah siswa menggunakan model pembelajaran berbasis masalah lebih tinggi daripada menggunakan pembelajaran konvensional. Hal ini ditunjukkan dari nilai pretes dan postes pada kelas eksperimen maupun kelas kontrol yang mengalami peningkatan, namun peningkatan signifikan terjadi pada kelas eksperimen. Kelas eksperimen nilai rata-rata pretes siswa adalah 31,67 dan nilai rata-rata postes 72,17 mengalami peningkatan sebesar 40,5 sedangkan pada kelas kontrol nilai rata-rata pretes adalah 29,33 dan nilai rata-rata postes 62,17 mengalami peningkatan sebesar 32,84.

Tingginya nilai kemampuan pemecahan masalah siswa pada kelas eksperimen disebabkan adanya pengaruh yang diberikan melalui model pembelajaran berbasis masalah. Model ini memberikan kebebasan bagi siswa untuk terlibat aktif dalam pembelajaran namun masih dalam bimbingan guru. Kemampuan pemecahan masalah siswa melibatkan memahami masalah, merencanakan cara penyelesaian, melaksanakan rencana, dan menafsirkan hasil atas masalah yang disajikan berkenaan dengan subbab materi yang dibahas.

Penilaian sikap siswa pada kelas eksperimen juga meningkat setiap pertemuannya. Nilai rata-rata pertemuan I adalah 54,817, nilai rata-rata pertemuan II adalah 61,30 , dan nilai rata-rata pertemuan III adalah 73,52. Sehingga rata-rata persentase penilaian sikap kelas eksperimen dengan menggunakan model pembelajaran berbasis masalah menggunakan macromedia flash adalah 63,21 yang termasuk dalam kategori baik sedangkan menggunakan pembelajaran konvensional rata-rata persentase adalah 61,61 yang termasuk dalam kategori baik. Selanjutnya untuk penilaian keterampilan siswa pada kelas eksperimen juga mengalami peningkatan setiap pertemuannya. Nilai rata-rata pertemuan I 
adalah 61,99 , nilai rata-rata pada pertemuan II adalah 67,33, dan nilai rata-rata pada pertemuan III adalah 70,66 . Sehingga rata-rata persentase keterampilan siswa di kelas eksperimen dengan menggunakan pembelajaran berbasis masalah menggunakan macromedia flash adalah 66,66 yang termasuk dalam kriteria baik. Kelas kontrol tidak memiliki penilaian keterampilan yang dinilai hanya observasi sikap, aktivitas dan hasil belajar pengetahuan, karena pada kelas kontrol tidak ada melakukan eksperimen maupun demonstrasi yang dilakukan oleh guru. Selanjutnya untuk penilaian aktivitas siswa pada kelas eksperimen dengan menggunakan model pembelajaran berbasis masalah menggunakan macromedia flash memiliki ratarata 78,86 yang termasuk dalam kriteria baik dan penilaian aktivitas siswa pada kelas kontrol dengan pembelajaran konvensional memiliki rata-rata 58,86 yang termasuk dalam kriteria cukup baik.

Hasil penelitian terdahulu juga menunjukkan adanya peningkatan kemampuan pemecahan masalah siswa Harsoyono dan Sopyan (2014), memaparkan Analisis kemampuan pemecahan masalah dengan analisis uji gain diperoleh untuk nilai pre-test dan post-test mengalami peningkatan sebesar $73 \%$ pada kelas eksperimen sedangkan pada kelas kontrol mengalami peningkatan sebesar $61 \%$. Penelitian tentang kemampuan pemecahan masalah juga dilakukan oleh Sujarwanto (2014), memaparkan perkembangan kemampuan pemecahan masalah fisika siswa setelah belajar dengan modeling instruction ditunjukkan dengan perkembangan yang lebih baik dalam mengenali masalah berdasarkan konsep, membuat representasi dari masalah, dan evaluasi terhadap solusi dan konsep yang digunakan dan peneliti selanjutnya dilakukan oleh Masek dan Yamin (2011), memaparkan Implikasinya adalah bahwa, kurikulum PBL harus dirancang dengan baik dan berkaitan pada unsur-unsur penting yang berkontribusi terhadap efektivitas PBL. Ini termasuk peran fasilitator dalam mediasi siswa belajar, terutama dalam memicu pemikiran meta-kognitif siswa. Dengan semua ini dengan pertimbangan yang baik, PBL dapat sukses seperti apa yang telah dicatat dalam teori.

Penggunaan model pembelajaran berbasis masalah dapat meningkatkan kemampuan pemecahan masalah siswa, namun masih ada kendala yang dihadapi peneliti selama penelitian. Kendala yang dihadapi selama penelitian terdapat pada fase kedua dan ketiga yaitu mengorganisasikan siswa untuk meneliti dan membantu investigasi mandiri dan kelompok siswa didalam fase ini siswa masih banyak kesulitan dalam melakukan investigasi mandiri dan peneliti kesusahan dalam mengorganisasikan siswa untuk meneliti hal ini terlihat melalui pada saat siswa diorganisasikan untuk meneliti dan melakukan investigasi mandiri siswa banyak yang tidak melakukan percobaan dan tidak disiplin selama praktikum dan tidak bertanggung jawab terhadap kelompoknya masing-masing melainkan menggangu kelompok lain yang sedang praktikum hal ini disebabkan oleh kurang kondusifnya kelas dan terlalu banyak jumlah siswa dalam satu kelompok sehingga siswa tidak bekerja sama dalam kelompok sehingga sebagian siswa pasif dalam kelompok tersebut. Untuk mengatasi kendala diatas peneliti selanjutnya diharapkan dapat mengkondusikan kelas dengan baik sehingga tidak terjadi keributan dalam pembelajaran, pembagian kelompok sebaiknya siswa $4-5$ orang dalam satu kelompok.

Arends (2008) menyatakan bahwa model problem based learning (PBL) adalah suatu pendekatan pembelajaran dimana siswa mengerjakan permasalahan yang autentik (nyata) dengan maksud untuk menyusun pengetahuan mereka sendiri. Adapun kelebihan dari pembelajaran berbasis masalahyaitusiswa didorong untuk memiliki kemampuan memecahkan masalah dalam situasi nyata (autentik), siswa memiliki kemampuan membangun pengetahuannya sendiri melalui kegiatan pembelajaran, siswa dapat memahami materi karena materi yang disajikan berupa masalah-masalah dalam kehidupan sehari-hari.

\section{KESIMPULAN DAN SARAN}

Berdasarkan hasil penelitian, peneliti mengambil simpulan berdasarkan analisis uji 
Seftia Agafe Br Barus dan Rappel Situmorang. Pengaruh Model Pembelajaran Berbasis Masalah Menggunakan Macromedia Flash Terhadap Kemampuan Pemecahan Masalah Siswa Pada Materi Pokok Fluida Dinamis Kelas XI Semester II SMA Negeri 2 Kabanjahe T.P.2015/2016

hipotesis diperoleh thitung $>$ ttabel $=3,73>1,988$ pada taraf signifikan $\alpha=0,05$, hal ini menyatakan ada pengaruh yang signifikan dari model pembelajaran berbasis masalah menggunakan macromedia Flash terhadap kemampuan pemecahan masalah siswa pada materi pokok fluida dinamis di kelas XI semester II SMA Negeri 2 Kabanjahe T.P. 2015/2016.

Berdasarkan hasil penelitian, maka peneliti mempunyai beberapa saran, yaitu:

1. Bagi peneliti selanjutnya disarankan agar menggunakan waktu seefisien mungkin dan mengkondisikan kelas dengan baik agar tercapai hasil yang efektif.

2. Untuk peneliti selanjutnya dalam mengorganisasikan siswa diharapkan jumlah siswa dalam kelompok 4-5 orang agar siswa dapat aktif dan dapat bekerja sama dalam kelompoknya dengan baik.

\section{DAFTAR PUSTAKA}

Arends, R.I., (2008),Learning to teach, Penerbit Pustaka Pelajar, Yogyakarta.

Harsoyono,I, T., A, Sopyan., Penerapan Model pembelajaran Berbasis Masalah dengan Teknik Probing-Prompting Untuk Meningkatkan Kemampuan Pemecahan Masalah IPA Siswa Kelas VII SMP, Unnes Physics Education Journal 3(2): 42-47

Khodizah, Rizki., (2015), Pengaruh Model Pembelajaran Berbasis Masalah Terhadap Hasil Belajar Siswa Kelas XI Semester Genap Pada Materi Pokok Fluida Dinamis Di SMA Negeri 11 Medan, Skripsi FMIPA, Unimed, Medan.

Masek, Alias., dan Sulaiman Yamin., (2011), The Effect of Problem Based Learning on Critical Thinking Ability: A Theoretical and Empirical Review, International Review of Social Sciences and Humanities2(1): 215-221

Rahayu, Sri. (2015). Pengaruh Model Pembelajaran Berbasis Masalah Terhadap Hasil Belajar Dan Aktivitas Siswa Pada Materi Pokok Listrik Dinamis Kelas $X$
Semester II Di SMA Muhammaddiyah 8 Kisaran T.A. 2014/2015, Skripsi FMIPA, Unimed, Medan

Rusman., (2010), Model-Model Pembelajaran Mengembangkan Profesionalisme Guru , Rajawali Pers, Jakarta.

Sinaga, Theresia.,(2015), Pengaruh Model Problem Based Learning (PBL) Terhadap Hasil Belajar Siswa Pada Materi Pokok Suhu Dan Kalor Di Kelas X Semester II SMA Negeri 3 Medan T.P. 2014/2015, Skripsi FMIPA, Unimed, Medan

Sudjana., (2005), Metode Statistika, Tarsito, Bandung.

Sujarwanto, E., A. Hidayat., dan Wartono., (2014), Kemampuan Pemecahan Masalah Fisika Pada Modelling Instruction Pada Siswa SMA Kelas XI, Jurnal Pendidikan IPA Indonesia 3(1): 65-78

Trianto., (2009), Mendesain Model Pembelajaran Inovatif Progresif, Kencana Prenada Media Grup, Jakarta. 